\title{
PROJECT MANAGEMENT OFFICE ACTION MODEL USING AHP
}

\author{
Shoso Yamato* \\ NEC Corporation \\ Tokyo, JAPAN \\ E-mail: yamatos@bl.jp.nec.com \\ Jinnosuke Nakamura \\ NTT DATA INTELLILINK CORPORATION \\ Tokyo, JAPAN \\ E-mail: nakamurajn@intellilink.co.jp \\ Toshihisa Honma \\ Graduate School of Information Science and Technology Hokkaido University \\ Sapporo, JAPAN \\ E-mail: honma@,ist.hokudai.ac.jp
}

\begin{abstract}
This paper proposes a prediction model structured by the Analytic Hierarchy Process (hereafter referred to as AHP), using a quantitative method for project assessment. Comparing the past performance values with the predicted values obtained by this proposed model has enabled to construct a model where the average of relative error between the values falls within the range of one percent, and the standard deviation ranges six to seven percent. Assuming that various factors correlate to reflect the project status, this model may be considered practically applicable.
\end{abstract}

Keywords: Project Management Office, PMO Action Model, Interdependence among Categories

\section{Introduction}

Quantitative evaluation of a project is very important to the stakeholders, and the project management office (hereafter referred to as PMO) is required to predict the project future based on the evaluation values, to identify the risks involved in the project, and to promptly take necessary actions. In other words, not only evaluating the current project status but predicting the future is effective to determine which actions PMO should take. The authors have developed the quantitative Project Assessment Indicator (hereafter referred to as PAI), and, with this architecture, have established a quantitative project assessment method applying AHP (Yamato, 2005) (Yamato, Nakamura, 2006). This paper describes a prediction model for project assessment applying AHP, which is constructed based on the above achievements (Saaty, 1980). This model is called the PMO Action Model, and its validity is verified in this paper. A series of actions including project assessment, decision making to take actions for a project, appealing to the stakeholders, and project prediction are called PMO actions.

Chapter 2 describes relationship between the structure of PAI and PMO action model, and shows the overall picture of PMO action model. The PAI allocated marks, structures of PAI evaluation functions, and the variations given to the PAI evaluation values by PMO actions are illustrated, and the components of three variations are described.

\footnotetext{
* Corresponding author
} 
Chapter 3 describes the variation vectors of each category, which indicates the priority of categories so that PMO actions should be preferentially taken on the categories with a lower degree of achievement.

Chapter 4 describes the levels of actions which PMO takes on a project, and defines the types of PMO actions to be taken according to the state of category.

Chapter 5 describes decision making on PMO actions, and examines new allocated marks of categories as the criteria for decision making based on the interdependence among categories.

Chapter 6 evaluates the precision of PMO action model. The relative errors between the predicted values obtained by PMO action model and the performance values obtained by PAI evaluation are defined, and the average value and the standard deviation are employed as the criteria of assessment.

Chapter 7 gives a conclusion of this paper.

\section{PAI and PMO Action Model}

PAI the authors has established in PMO activities since 2005 monitors the state of a project, and assesses it for 15 categories classified into eight process categories and seven result categories. Table 1 lists the categories and allocated marks to these categories (Yamato, 2005) (Yamato, Nakamura, 2006) .

Table 1. Allocated Marks of 15 Categories

\begin{tabular}{l|c|l|c}
\hline Process Categories & Allocated Marks & Result Categories & Allocated Marks \\
\hline Financial process & 3 & Financial result & 17 \\
Customers process & 3 & Customers result & 7 \\
Review process & 2 & Review result & 8 \\
Progress process & 8 & Progress result & 12 \\
Performance process & 4 & Performance result & 6 \\
Quality process & 5 & Quality result & 5 \\
Human Resource process & 5 & Human Resource result & 5 \\
Risk process & 10 & & \\
\hline Allocated Marks of Process & 40 & Allocated Marks of Result & 60 \\
Categories in total & & Categories in total & \\
\hline & & Total Allocated Marks & 100 \\
\hline
\end{tabular}

A project is assessed by the PAI evaluation function described below, and the allocated marks listed in the above table are used. Suppose that $\mathrm{f}(\mathrm{x})$ is the evaluation function for process categories $\mathrm{x}_{\mathrm{i}},(\mathrm{i}=1,2, \ldots, 8)$, and $g(x)$ is the evaluation function for the result categories $y_{i},(i=1,2, \ldots, 7)$. The PAI evaluation function for an entire project is:

$\mathrm{h}(\mathrm{z})=\mathrm{f}(\mathrm{x})+\mathrm{g}(\mathrm{y})=\mathrm{f}\left(\mathrm{x}_{1}, \mathrm{x}_{2}, \ldots \mathrm{x}_{8}\right)+\mathrm{g}\left(\mathrm{y}_{1}, \mathrm{y}_{2}, \ldots \mathrm{y}_{7}\right)$

where $z_{i}=\left\{\begin{array}{cc}x_{i} & 1 \leq i \leq 8 \\ y_{i-8} & 9 \leq i \leq 15\end{array}\right.$

In the following expressions, the PAI evaluation values are obtained when time has elapsed from the time $\mathrm{t}$ to the time $\Delta \mathrm{t}$. Suppose that the values of the process categories and result categories have changed by $\Delta \mathrm{x}$ and $\Delta \mathrm{y}$, respectively, the entire evaluation function is as follows according to the Taylor expansion (Abramowitz; Stegun, 1970). 


$$
\begin{aligned}
& \mathrm{h}(\mathbf{z}+\Delta \mathbf{z})=\mathrm{f}(\mathbf{x}+\Delta \mathbf{x})+\mathrm{g}(\mathbf{y}+\Delta \mathbf{y}) \\
& =\mathrm{f}(\mathbf{x})+\sum_{\mathrm{i}=1}^{8} \frac{\partial \mathrm{f}}{\partial \mathrm{x}_{\mathrm{i}}} \Delta \mathrm{x}_{\mathrm{i}}+\cdots+\mathrm{g}(\mathbf{y})+\sum_{\mathrm{i}=1}^{7} \frac{\partial \mathrm{g}}{\partial \mathrm{y}_{\mathrm{i}}} \Delta \mathrm{y}_{\mathrm{i}}+\cdots \\
& \equiv \mathrm{h}(\mathbf{z})+\Delta \mathrm{h}(\mathbf{z})+\cdots
\end{aligned}
$$

The variation $\Delta \mathrm{h}$ of the evaluation function $\mathrm{h}$ is approximated by the following expression:

$$
\therefore \Delta \mathrm{h}(\mathrm{z})=\sum_{\mathrm{i}=1}^{8} \frac{\partial \mathrm{f}}{\partial \mathrm{x}_{\mathrm{i}}} \Delta \mathrm{x}_{\mathrm{i}}+\sum_{\mathrm{i}=1}^{7} \frac{\partial \mathrm{g}}{\partial \mathrm{y}_{\mathrm{i}}} \Delta \mathrm{y}_{\mathrm{i}}=\sum_{\mathrm{i}=1}^{15} \frac{\partial \mathrm{h}}{\partial \mathrm{z}_{\mathrm{i}}} \Delta \mathrm{z}_{\mathrm{i}}
$$

The above definition corresponds to the extension of three-dimensional convective derivative to the multi-dimensional space.

Based on the above expression (3), the authors have formulated the following expression as a PMO action model of the variation $\Delta \mathrm{h}$ for the PAI evaluation function which changes on a monthly basis (Yamato, Nakamura, and Honma, 2008b).

$$
\Delta \mathrm{h}=\sum_{\mathrm{i}}^{15} \Omega_{\mathrm{i}}\left(\omega_{\mathrm{i}}\right)(\operatorname{Sgn})_{\mathrm{i}} \omega_{\mathrm{i}} \Delta \mathrm{z}_{\mathrm{i}}^{\mathrm{m}}
$$

where,

$(\mathrm{Sgn})_{\mathrm{i}} \quad$ : Variation direction of category i (decision making on PMO action)

$\Omega_{\mathrm{i}}\left(\omega_{\mathrm{i}}\right) \quad$ : Magnitude of variation ratio of category $\mathrm{i}$ in function $\mathrm{h}$ (action level)

$\omega_{\mathrm{i}} \Delta \mathrm{z}_{\mathrm{i}}^{\mathrm{m}} \quad:$ Variation of category i per unit time

$\omega_{i} \quad:$ Weight of non-achievement ratio of category $i$

$z_{i}^{m}=z_{i}^{+}-z_{i} \quad$ : Maximum variation of category $i$

The following paragraph explains what the above expression (4) means from the viewpoint of project assessment.

The increment or decrement of the evaluation value in each category is represented by the three variables: Sgn, $\Omega$, and $\omega$. (Sgn) indicates decision making on whether or not PMO takes actions for project improvement based on the PAI values of each category. $\Omega_{\mathrm{i}}$ indicates the strength level of the action PMO takes for a project. $\omega$ is the weight of non-achievement ratio to the allocated marks of each category.

Therefore, the expression (4) is a modeling for PMO to observe the PAI values of a project, to take necessary PMO actions such as consultation and advice to relevant categories, to bring about improvement, and to predict the effect. 
The following figure shows the overall picture of PMO action model (Yamato, Nakamura, and Honma, 2008b)

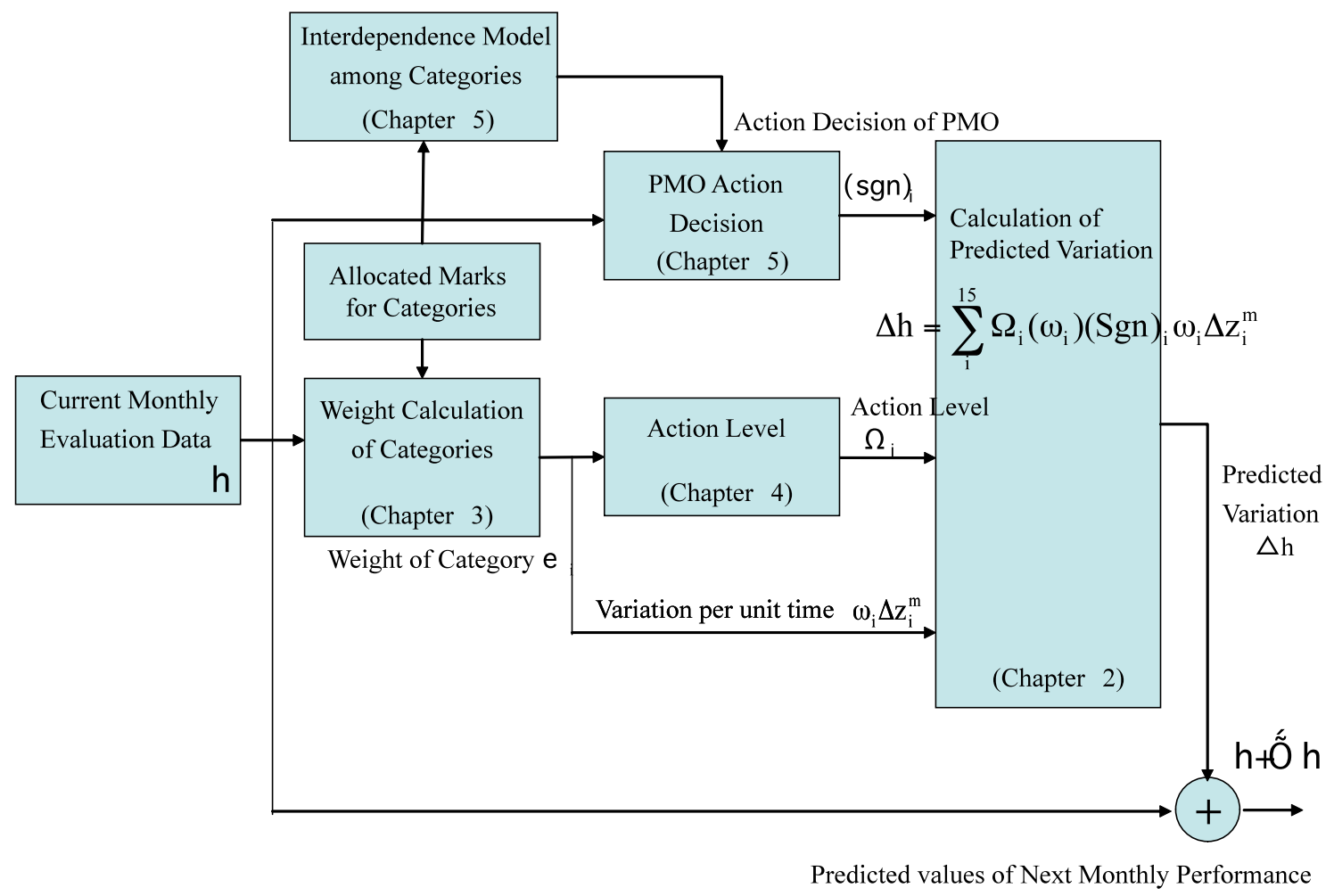

Figure 1. PMO Action Model

\section{Variation Vectors of Each Category}

In the following expressions, the weight of non-achievement ratio is obtained by each category. (Yamato, Nakamura, and Honma, 2008b). After evaluating a project, if the non-achievement ratio of a target category (= ((allocated marks of category - evaluation value) / allocated marks of category $) \times 100)$ is high, some sort of PMO actions are required to take preferentially to improve the state of the category.

The concrete expression to obtain $\Delta \mathrm{h}(\mathrm{z})$ is:

$$
\Delta \mathrm{h}(\mathbf{z})=\sum_{\mathrm{i}=1}^{\mathrm{n}} \frac{\partial \mathrm{h}}{\partial \mathrm{z}_{\mathrm{i}}} \Delta \mathrm{z}_{\mathrm{i}}=\sum_{\mathrm{i}=1}^{\mathrm{n}} \frac{\partial \mathrm{h}}{\partial \mathrm{z}_{\mathrm{i}}}\left(\omega_{\mathrm{i}} \Delta \mathrm{z}_{\mathrm{i}}^{\mathrm{m}}\right)
$$

Where, suppose that the allocated mark of category i is $z_{i}^{+}$, the maximum variation of $\Delta z_{i}$ is $z_{i}^{m}=z_{i}^{+}-z_{i}$, then $\Delta z_{i}$ is given as follows:

$$
\Delta \mathbf{z}=\boldsymbol{\omega} \Delta \mathbf{z}^{\mathrm{m}}=\left(\begin{array}{cccc}
\omega_{1} & 0 & 0 & 0 \\
0 & \omega_{2} & 0 & 0 \\
0 & 0 & \ldots & 0 \\
0 & 0 & 0 & \omega_{8}
\end{array}\right)\left(\begin{array}{c}
\Delta \mathrm{z}_{1}{ }^{\mathrm{m}} \\
\Delta \mathbf{z}^{\mathrm{m}} \\
\vdots \\
\Delta \mathrm{z}_{8}{ }^{\mathrm{m}}
\end{array}\right)=\left(\begin{array}{c}
\omega_{1} \Delta \mathrm{z}_{1}{ }^{\mathrm{m}} \\
\omega_{2} \Delta \mathrm{z}_{2}{ }^{\mathrm{m}} \\
\vdots \\
\omega_{8} \Delta \mathrm{z}_{8}{ }^{\mathrm{m}}
\end{array}\right)
$$


However, assume that the non-achievement ratio of category $i$ is $\Delta z_{i}^{m} / z_{i}^{+}$, the weight of the nonachievement ratio of category $i$ is defined as follows and the value ranges $0 \leq \omega_{i} \leq 1$.

$$
\omega_{i}=\left(\Delta z_{i}^{m} / z_{i}^{+}\right) /\left(\sum_{i=1}^{n} \Delta z_{i}^{m} / z_{i}^{+}\right)
$$

Consequently, $\omega$ is a diagonal matrix of the weight of the non-achievement ratio.

The weight of Non-achievement ratio of Category i

$$
\begin{aligned}
& \omega_{\mathrm{i}}=\left(\Delta \mathrm{z}_{\mathrm{i}}^{\mathrm{m}} / \mathrm{z}_{\mathrm{i}}^{+}\right) /\left(\sum_{\mathrm{i}=1}^{\mathrm{n}} \Delta \mathrm{z}_{\mathrm{i}}^{\mathrm{m}} / \mathrm{z}_{\mathrm{i}}^{+}\right) \\
& 0 \leq \omega_{\mathrm{i}} \leq 1
\end{aligned}
$$

Non- achievement ratio of Category i $\quad \Delta z_{i}^{m} / z_{i}^{+}$

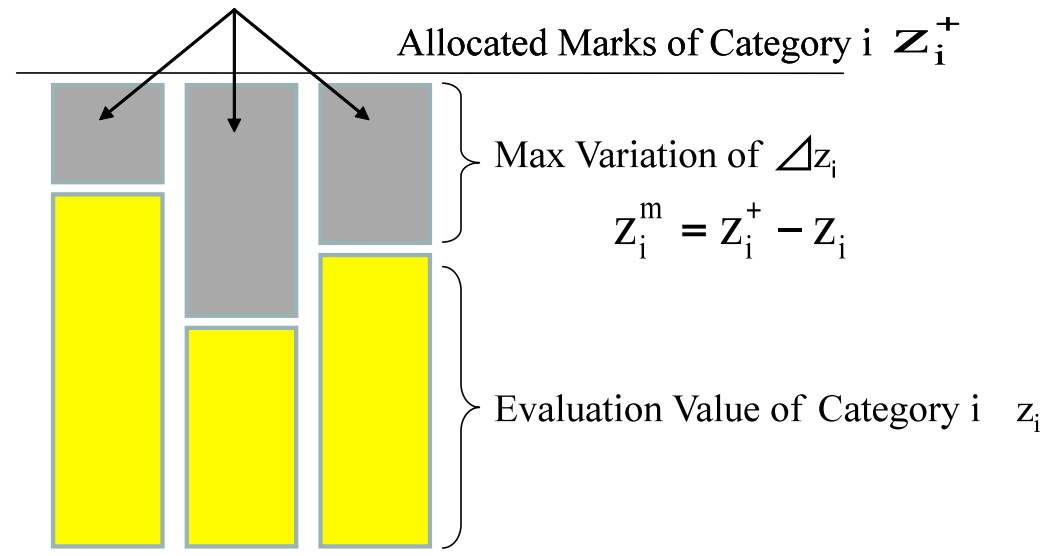

Figure 2. The weight of Non-achievement ratio of Category i $\omega_{i}$

\section{Action Levels}

The maximum variation $\Delta z_{i}^{m}$ of the evaluation function of category $i$ is as follows:

$$
\Delta \mathrm{h}\left(\Delta \mathrm{z}_{\mathrm{i}}^{\mathrm{m}}\right)=\mathrm{z}_{\mathrm{i}}^{+}-\mathrm{z}_{\mathrm{i}}=\Delta \mathrm{z}_{\mathrm{i}}^{\mathrm{m}}
$$

Thus, the maximum variation ration of the evaluation value 1 is obtained by the following expression:

$$
\lim _{\Delta \mathrm{z}_{\mathrm{i}}^{\mathrm{m}} \rightarrow 0} \Delta \mathrm{h}\left(\Delta \mathrm{z}_{\mathrm{i}}^{\mathrm{m}}\right) / \Delta \mathrm{z}_{\mathrm{i}}^{\mathrm{m}}=\frac{\partial \mathrm{h}}{\partial \mathrm{z}_{\mathrm{i}}^{\mathrm{m}}}=1
$$

Suppose that the magnitude $\Omega_{\mathrm{i}}$ of the variation of category evaluation function is given not exceeding 1 , and when the variation $\Delta z_{i}$ is expressed by the change $\Delta \omega_{i}$ of the weight $\omega_{i}$, the tiny variation is $\mathrm{dz} \mathrm{z}_{\mathrm{i}}=\Delta \mathrm{z}_{\mathrm{i}}^{\mathrm{m}} \mathrm{d} \omega_{\mathrm{i}}$.

Consequently, the magnitude of the variation of the evaluation function value is as follows: 
$\left|\partial \mathrm{h} \partial \mathrm{z}_{\mathrm{i}}\right|=\left|\partial\left(\mathrm{h} / \Delta \mathrm{z}_{\mathrm{i}}^{\mathrm{m}}\right) / \partial \omega_{\mathrm{i}}\right|=\left|\partial \mathrm{h}^{*} / \partial \omega_{\mathrm{i}}\right|=\Omega_{\mathrm{i}}<1$

where $\mathrm{h}^{*}=\mathrm{h} / \Delta \mathrm{z}_{\mathrm{i}}^{\mathrm{m}}$ is a normalized evaluation function, and $\Omega_{\mathrm{i}}=\left|\partial \mathrm{h}^{*} / \partial \omega_{\mathrm{i}}\right|$ is called PMO action level . (Yamato, Nakamura, and Honma, 2008b)

Since the magnitude $\Omega_{\mathrm{i}}$ of the action level is given by the derivative of the weight of nonachievement ratio of category $i$, assume the cases as PMO actions where the derivative value $\omega_{i}$ is an increasing function, constant function, or decreasing function. The respective action level $\Omega_{\mathrm{i}}$ is called level-increasing type, constant-level type, or level decreasing type.

Each type corresponds to what action PMO should take for a project; e.g., for a project with fewer nonachievement categories, for a project with no relationship with the number of non-achievement categories, or for a project with a greater number of non-achievement categories.

The weight $\omega_{i}$ of non-achievement ratio of category $i$ is divided into five: $\omega_{i}=0,0<\omega_{i} \leq 0.20,0.20<\omega_{i} \leq 0.40,0.40<\omega_{i} \leq 0.60,0.60<1.00$ based on the actual PAI evaluation.

For the magnitude $\Omega_{\mathrm{i}}$ of action level, the value corresponding to the division of the weight $\omega_{\mathrm{i}}$ of nonachievement ratio of category $\mathrm{i}$ is set applying the AHP absolute evaluation method (Saaty, 1980) (Yamato, Nakamura, and Honma, 2008a).

\subsection{What action to take for a project with a fewer number of non-achievement categories}

There are a fewer number of non-achievement categories, which means there are a greater number of fullmark categories, and it may be judged that there are several categories with higher non-achievement ratio. In this case, PMO should take actions of higher levels for the limited categories. Namely, the action levels of increasing function type are effective. Taking this type of actions is appropriate for a project with higher maturity, that is, taking actions of level increasing type shown Figure 3 is suitable.

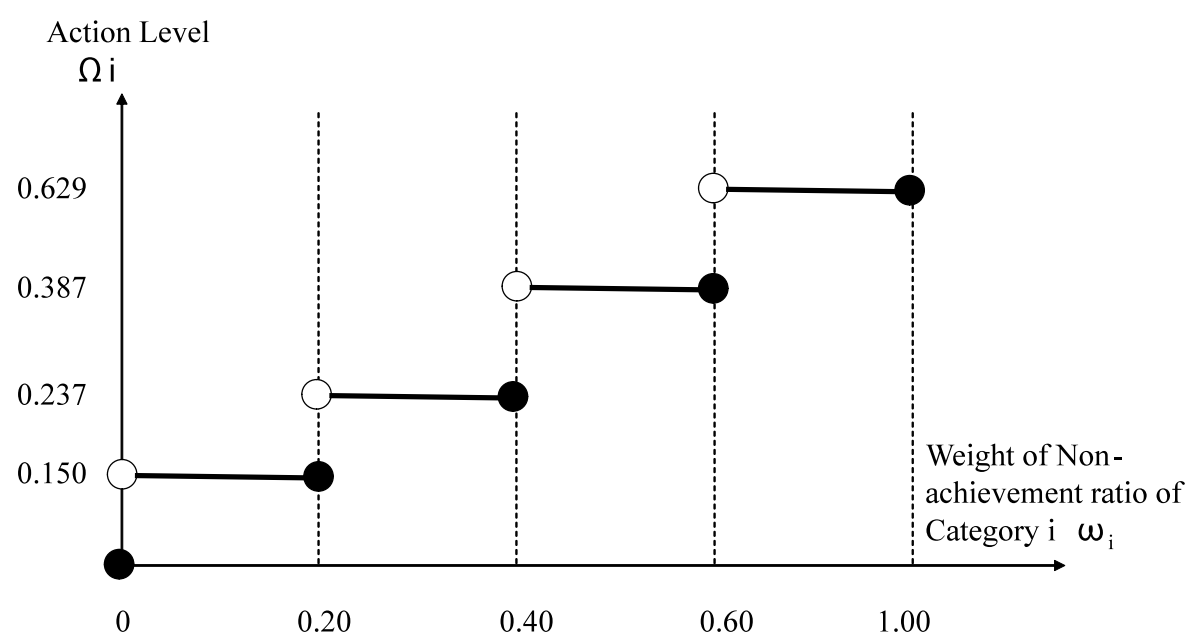

Figure 3. Level Increasing Type Action Level $\Omega \mathrm{i}$

\subsection{What action to take for a project with a greater number of non-achievement categories}

When there are a greater number of non-achievement categories, it is considered that there are a greater number of categories with a lower weight of non-achievement ratio. In such cases as these projects, PMO 
should take actions of higher levels for the categories of lower non-achievement level. Namely, the action levels of decreasing function type should be employed. When taking this type of actions, it is assumed that taking actions of level decreasing type shown in Figure 4 is appropriate.

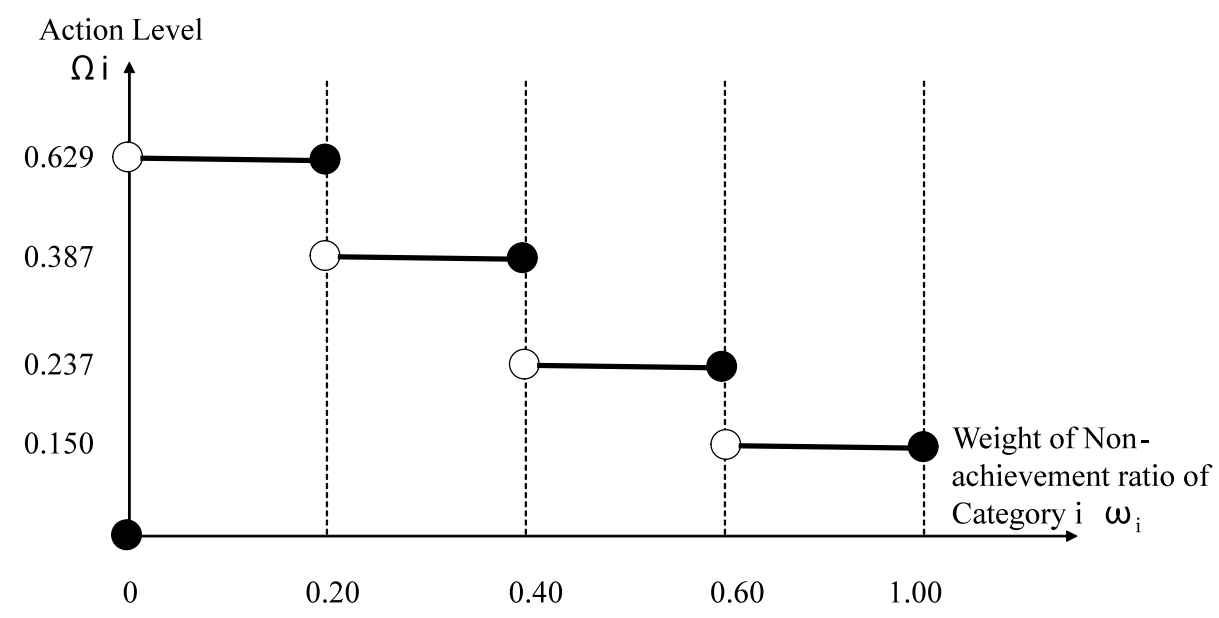

Figure 4. Level Decreasing Type Action Level $\Omega \mathrm{i}$

\subsection{What action to take for a project with no relationship with the number of non-achievement categories}

When there are non-achievement categories, actions with constant action levels should be taken. It may be considered that PMO implements the action level on their stance with little relation with the project state. Figure 5 shows the constant-level type action level $\Omega \mathrm{i}(\Omega \mathrm{i}=0.629)$.

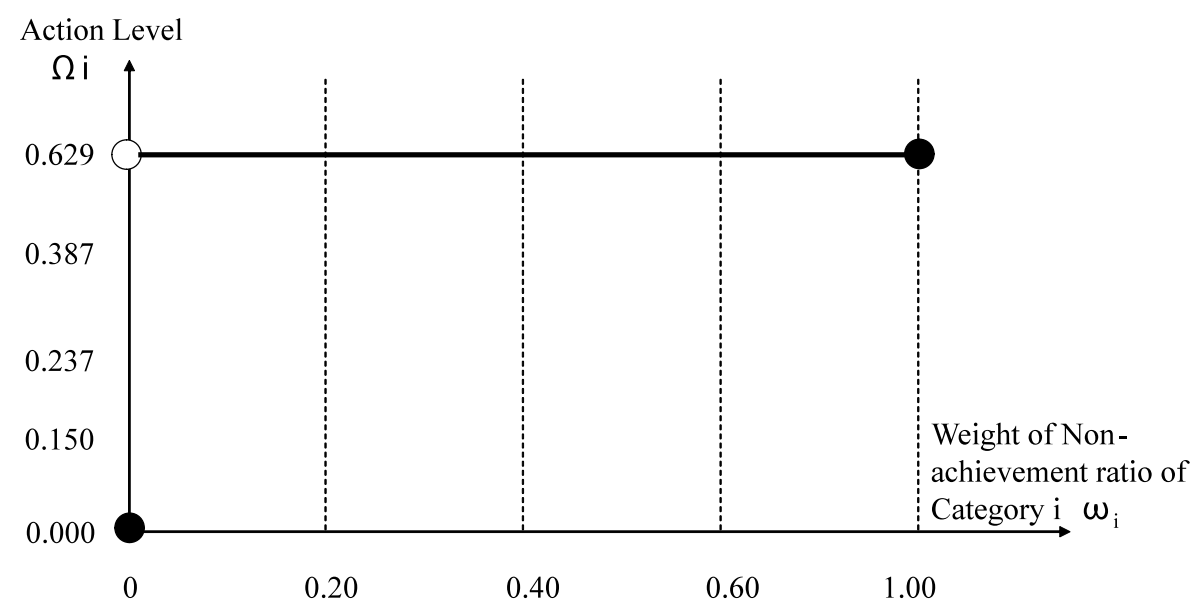

Figure 5 Constant-level Type Action Level $\Omega i(\Omega i=0.629)$ 


\section{Decision Making on PMO Action}

Categories are interdependent. The interdependence model among categories the authors have plotted is as shown in Figure 6 (Yamato, Nakamura, and Honma, 2008b).

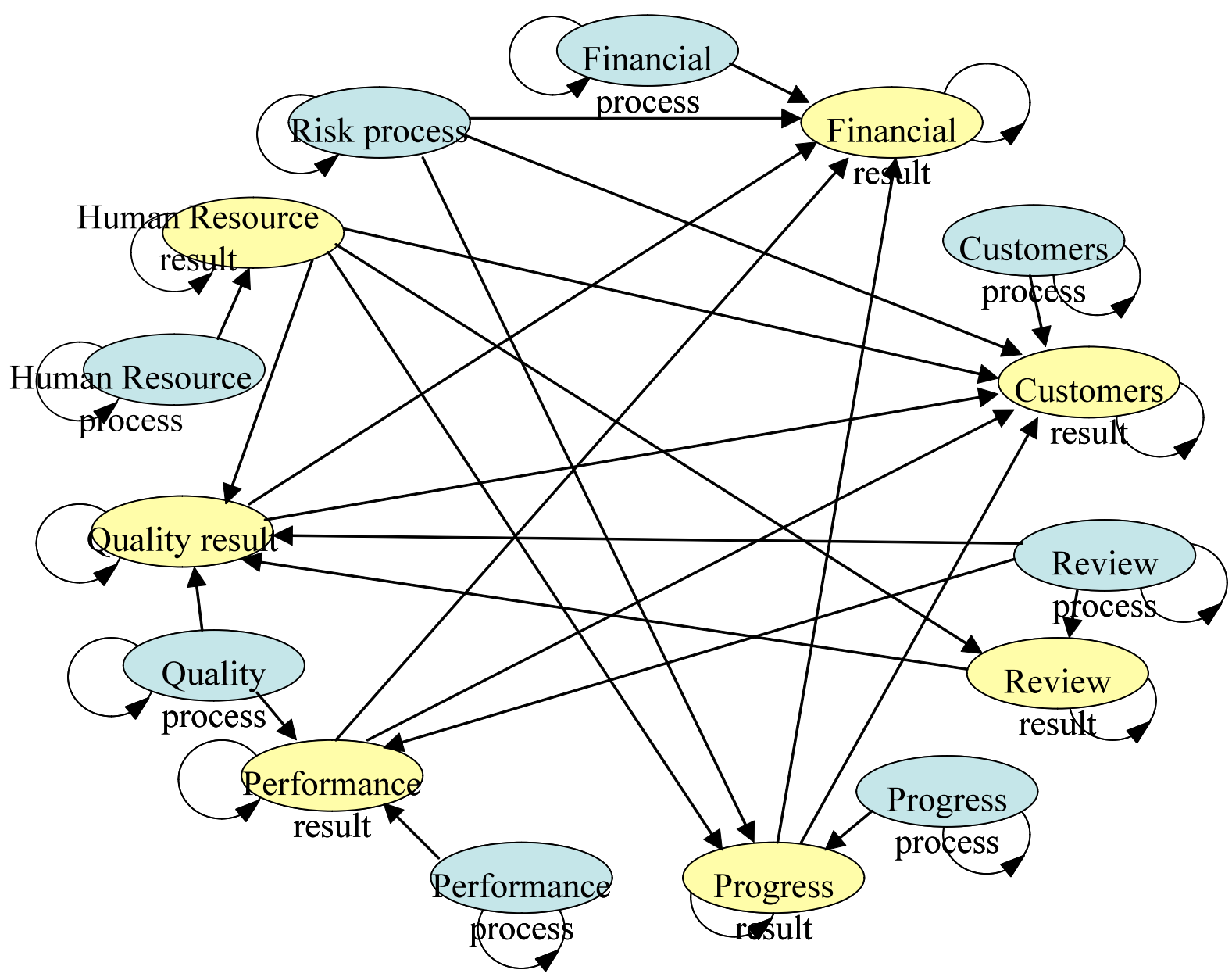

Figure 6. Interdependence Model among Categories

The above figure indicates, for example, the evaluation of Customers result category is affected not only by the evaluation of Customer process but by the evaluations of Progress process, performance process, quality process, Human Resource process, and Risk process.

To clarify the interdependence among categories based on Figure 6, pairwise comparison is made among the categories as shown in Table 2.

To precisely measure the degree of influence, the affected categories (those with arrows directed to) and affecting categories (those with arrow directing outward) are compared in pairs. Since the Consistency Index (C.I.) in each pairwise comparison is less than 0.1, it may be determined that the comparison is made consistently (Saaty, 1980). 
Table 2. Pairwise Comparison Matrixes of Interdependence Relation

\begin{tabular}{|l|c|c|c|c|c|c|}
\hline $\begin{array}{l}\text { Financial } \\
\text { result }\end{array}$ & $\begin{array}{l}\text { Financial } \\
\text { process }\end{array}$ & $\begin{array}{l}\text { Financial } \\
\text { result }\end{array}$ & $\begin{array}{l}\text { Progress } \\
\text { result }\end{array}$ & $\begin{array}{l}\text { Performan } \\
\text { ce result }\end{array}$ & $\begin{array}{l}\text { Quality } \\
\text { result }\end{array}$ & $\begin{array}{l}\text { Risk } \\
\text { process }\end{array}$ \\
\hline $\begin{array}{l}\text { Financial } \\
\text { process }\end{array}$ & 1 & $1 / 5$ & $1 / 2$ & $1 / 2$ & $1 / 2$ & 2 \\
\hline $\begin{array}{l}\text { Financial } \\
\text { result }\end{array}$ & 5 & 1 & 3 & 3 & 2 & 2 \\
\hline $\begin{array}{l}\text { Progress } \\
\text { result }\end{array}$ & 2 & $1 / 3$ & 1 & 2 & 1 & 2 \\
\hline $\begin{array}{l}\text { Performan } \\
\text { ce result }\end{array}$ & 2 & $1 / 3$ & $1 / 2$ & 1 & $1 / 2$ & 3 \\
\hline $\begin{array}{l}\text { Quality } \\
\text { result }\end{array}$ & 2 & $1 / 2$ & 1 & 2 & 1 & 2 \\
\hline $\begin{array}{l}\text { Risk } \\
\text { process }\end{array}$ & $1 / 2$ & $1 / 2$ & $1 / 2$ & $1 / 3$ & $1 / 2$ & 1 \\
\hline
\end{tabular}

\begin{tabular}{|c|c|c|c|c|c|c|c|}
\hline \multicolumn{2}{|c|}{$\lambda_{\max }=6.302$} & \multicolumn{3}{|c|}{ C.I. $=0.060$} & \multirow[b]{2}{*}{$\begin{array}{l}\text { Quality } \\
\text { result }\end{array}$} & \multirow[b]{2}{*}{$\begin{array}{l}\text { Human- } \\
\text { R result }\end{array}$} & \multirow[b]{2}{*}{$\begin{array}{l}\begin{array}{l}\text { Risk } \\
\text { process }\end{array} \\
\end{array}$} \\
\hline $\begin{array}{l}\text { Customers } \\
\text { result }\end{array}$ & $\begin{array}{l}\text { Customers } \\
\text { process }\end{array}$ & $\begin{array}{l}\text { Customers } \\
\text { result }\end{array}$ & $\begin{array}{l}\text { Progress } \\
\text { result }\end{array}$ & $\begin{array}{l}\text { Performan } \\
\text { ce result }\end{array}$ & & & \\
\hline $\begin{array}{l}\text { Customers } \\
\text { process }\end{array}$ & 1 & $1 / 2$ & $1 / 2$ & $1 / 2$ & $1 / 2$ & 3 & 3 \\
\hline $\begin{array}{l}\text { Customers } \\
\text { result }\end{array}$ & 2 & 1 & 2 & 2 & 2 & 3 & 3 \\
\hline $\begin{array}{l}\text { Progress } \\
\text { result }\end{array}$ & 2 & $1 / 2$ & 1 & 1 & $1 / 2$ & 1 & 1 \\
\hline $\begin{array}{l}\text { Performan } \\
\text { ce result }\end{array}$ & 2 & $1 / 2$ & 1 & 1 & 2 & 3 & 4 \\
\hline $\begin{array}{l}\text { Quality } \\
\text { result }\end{array}$ & 2 & $1 / 2$ & 2 & 2 & 1 & 4 & 3 \\
\hline $\begin{array}{l}\text { Human-R } \\
\text { result }\end{array}$ & $1 / 3$ & $1 / 3$ & 1 & 1 & $1 / 4$ & 1 & 1 \\
\hline $\begin{array}{l}\text { Risk } \\
\text { process }\end{array}$ & $1 / 3$ & $1 / 3$ & 1 & 1 & $1 / 3$ & 1 & 1 \\
\hline
\end{tabular}

\begin{tabular}{|c|c|c|c|}
\hline$\lambda_{\max }=7.469$ & \multicolumn{2}{c|}{ C.I. $=0.078$} \\
\hline $\begin{array}{c}\text { Review } \\
\text { result }\end{array}$ & $\begin{array}{c}\text { Review } \\
\text { process }\end{array}$ & $\begin{array}{c}\text { Review } \\
\text { result }\end{array}$ & $\begin{array}{l}\text { Human-R } \\
\text { result }\end{array}$ \\
\hline $\begin{array}{c}\text { Review } \\
\text { process }\end{array}$ & 1 & $1 / 2$ & 3 \\
\hline $\begin{array}{c}\text { Review } \\
\text { result }\end{array}$ & 2 & 1 & 2 \\
\hline $\begin{array}{l}\text { Human-R } \\
\text { result }\end{array}$ & $1 / 3$ & $1 / 2$ & 1 \\
\hline
\end{tabular}

\begin{tabular}{|c|c|c|c|c|}
\hline Progress result & $\begin{array}{c}\text { Progress } \\
\text { process }\end{array}$ & $\begin{array}{l}\text { Progress } \\
\text { result }\end{array}$ & $\begin{array}{l}\text { Human-R } \\
\text { result }\end{array}$ & Risk process \\
\hline $\begin{array}{c}\text { Progress } \\
\text { process }\end{array}$ & 1 & $1 / 2$ & 3 & 3 \\
\hline Progress result & 2 & 1 & 5 & 3 \\
\hline $\begin{array}{c}\text { Human-R } \\
\text { result }\end{array}$ & $1 / 3$ & $1 / 5$ & 1 & $1 / 2$ \\
\hline Risk process & $1 / 3$ & $1 / 3$ & 2 & 1 \\
\hline & $\lambda_{\max }=4.065$ & C.I. $=0.022$ \\
\hline
\end{tabular}

\begin{tabular}{|l|c|c|c|c|}
\hline $\begin{array}{l}\text { Performance } \\
\text { result }\end{array}$ & $\begin{array}{l}\text { Review } \\
\text { process }\end{array}$ & $\begin{array}{l}\text { Performan } \\
\text { ce process }\end{array}$ & $\begin{array}{l}\text { Performan } \\
\text { ce result }\end{array}$ & $\begin{array}{c}\text { Quality } \\
\text { process }\end{array}$ \\
\hline Review process & 1 & $1 / 2$ & $1 / 3$ & $1 / 2$ \\
\hline $\begin{array}{l}\text { Performance } \\
\text { process }\end{array}$ & 2 & 1 & $1 / 2$ & 1 \\
\hline $\begin{array}{l}\text { Performance } \\
\text { result }\end{array}$ & 3 & 2 & 1 & 1 \\
\hline Quality process & 2 & 1 & 1 & 1 \\
\hline
\end{tabular}

\begin{tabular}{|l|c|c|c|c|}
\hline \multicolumn{1}{c|}{$\lambda_{\max }=4.046$} & \multicolumn{3}{c|}{ C.I. $=0.015$} \\
\hline Quality result & $\begin{array}{c}\text { Review } \\
\text { process }\end{array}$ & $\begin{array}{c}\text { Review } \\
\text { result }\end{array}$ & $\begin{array}{c}\text { Quality } \\
\text { process }\end{array}$ & Quality result \\
\hline Review process & 1 & $1 / 2$ & $1 / 2$ & $1 / 3$ \\
\hline Review result & 2 & 1 & 2 & $1 / 2$ \\
\hline Quality process & 2 & $1 / 2$ & 1 & 2 \\
\hline Quality result & 3 & 2 & $1 / 2$ & 1 \\
\hline
\end{tabular}

\begin{tabular}{|c|c|c|c|}
\hline \multicolumn{2}{|c|}{$\lambda_{\max }=4.242$} & C.I. & $=0.081$ \\
\hline $\begin{array}{l}\text { Human-R } \\
\text { result }\end{array}$ & $\begin{array}{l}\text { Human-R } \\
\text { process }\end{array}$ & $\begin{array}{l}\text { Human-R } \\
\text { result }\end{array}$ & \\
\hline $\begin{array}{l}\text { Human- } R \\
\text { process }\end{array}$ & 1 & $1 / 3$ & \\
\hline $\begin{array}{l}\text { Human- } \mathrm{R} \\
\text { result }\end{array}$ & 3 & 1 & \\
\hline
\end{tabular}


From the above pairwise comparison matrixes, a dependence comparison matrix $\mathrm{M}$ as shown in Table 3 is obtained (Saaty, 1980) (Yamato, Nakamura, and Honma ,2008b).

Table 3. Dependence Matrix M

\begin{tabular}{|c|c|c|c|c|c|c|c|c|c|c|c|c|c|c|c|}
\hline & \begin{tabular}{|l|}
$\begin{array}{l}\text { Financial } \\
\text { Process }\end{array}$ \\
\end{tabular} & \begin{tabular}{|l} 
Customers \\
process
\end{tabular} & \begin{tabular}{|l|}
$\begin{array}{l}\text { Review } \\
\text { process }\end{array}$ \\
\end{tabular} & \begin{tabular}{|l}
$\begin{array}{l}\text { Progress } \\
\text { process }\end{array}$ \\
\end{tabular} & \begin{tabular}{|l|}
$\begin{array}{l}\text { Performance } \\
\text { process }\end{array}$ \\
\end{tabular} & $\begin{array}{l}\text { Quality } \\
\text { process }\end{array}$ & \begin{tabular}{|l}
$\begin{array}{l}\text { Human } \\
\text { Resource } \\
\text { process }\end{array}$ \\
\end{tabular} & Risk process & \begin{tabular}{|l|}
$\begin{array}{l}\text { Financial } \\
\text { result }\end{array}$ \\
\end{tabular} & \begin{tabular}{|l} 
Customers \\
result
\end{tabular} & \begin{tabular}{|l|}
$\begin{array}{l}\text { Review } \\
\text { result }\end{array}$ \\
\end{tabular} & \begin{tabular}{|l}
$\begin{array}{l}\text { Progress } \\
\text { result }\end{array}$ \\
\end{tabular} & \begin{tabular}{|l|}
$\begin{array}{l}\text { Performance } \\
\text { result }\end{array}$ \\
\end{tabular} & \begin{tabular}{|}
$\begin{array}{l}\text { Quality } \\
\text { result }\end{array}$ \\
\end{tabular} & \begin{tabular}{|l}
$\begin{array}{l}\text { Human } \\
\text { Resource } \\
\text { result }\end{array}$ \\
\end{tabular} \\
\hline $\begin{array}{l}\text { Financial } \\
\text { Process }\end{array}$ & 1.000 & & & & & & & & 0.091 & & & & & & \\
\hline $\begin{array}{l}\text { Customers } \\
\text { process }\end{array}$ & & 1.000 & & & & & & & & 0.120 & & & & & \\
\hline $\begin{array}{l}\text { Review } \\
\text { process }\end{array}$ & & & 1.000 & & & & & & & & 0.350 & & 0.124 & 0.149 & \\
\hline $\begin{array}{l}\text { Progress } \\
\text { process }\end{array}$ & & & & 1.000 & & & & & & & & 0.298 & & & \\
\hline $\begin{array}{l}\text { Performance } \\
\text { process }\end{array}$ & & & & & 1.000 & & & & & & & & 0.234 & & \\
\hline $\begin{array}{l}\text { Quality } \\
\text { process }\end{array}$ & & & & & & 1.000 & & & & & & & 0.278 & 0.335 & \\
\hline $\begin{array}{l}\text { Human } \\
\text { Resource } \\
\text { process }\end{array}$ & & & & & & & 1.000 & & & & & & & & 0.250 \\
\hline Risk process & & & & & & & & 1.000 & 0.086 & 0.066 & & 0.143 & & & \\
\hline $\begin{array}{l}\text { Financial } \\
\text { result }\end{array}$ & & & & & & & & & 0.350 & & & & & & \\
\hline $\begin{array}{l}\text { Customers } \\
\text { result }\end{array}$ & & & & & & & & & & 0.250 & & & & & \\
\hline $\begin{array}{l}\text { Review } \\
\text { result }\end{array}$ & & & & & & & & & & & 0.478 & & & & \\
\hline $\begin{array}{l}\text { Progress } \\
\text { result }\end{array}$ & & & & & & & & & 0.169 & 0.120 & & 0.473 & & & \\
\hline $\begin{array}{l}\text { Performance } \\
\text { result }\end{array}$ & & & & & & & & & 0.136 & 0.197 & & & 0.365 & & \\
\hline $\begin{array}{l}\text { Quality } \\
\text { result }\end{array}$ & & & & & & & & & 0.169 & 0.180 & & & & 0.314 & \\
\hline $\begin{array}{l}\text { Human } \\
\text { Resource } \\
\text { result }\end{array}$ & & & & & & & & & & 0.067 & 0.172 & 0.087 & & & 0.750 \\
\hline
\end{tabular}

Using the dependence matrix $\mathbf{M}$ indicating the dependency among categories and the weight $\mathbf{W}$, the revised weight $\mathbf{R}(=\mathbf{M W})$, which is the true weight, is calculated as shown in Table 4.

Table 4 indicates that the weight should be increased if $\mathrm{Ri}-\mathrm{Wi}>0$, and should be decreased if $\mathrm{Ri}-\mathrm{Wi}<$ 0 . Through the examination of the dependency, it has been found out that more marks should be allocated for the process categories, and fewer marks should be allocated to the result categories. Conventional allocation of marks was $40 \%$ for process categories and $60 \%$ for result categories, however, considering the dependency among categories, it has been found out that the desirable allocation of marks is reverse; $60 \%$ for process categories and $40 \%$ for result categories (Yamato, Nakamura, and Honma, 2008a) (Yamato, Nakamura, and Honma, 2008b). 
Table 4. Gap between Revised Value and Weight of Categories

\begin{tabular}{|c|c|c|c|c|c|c|}
\hline & Weight : W & $\begin{array}{c}\text { Revised } \\
\text { Weight : } R\end{array}$ & R-W & $\begin{array}{c}(\mathrm{R}-\mathrm{W}) / \mathrm{W} \\
\quad) \\
\mathrm{X100}(\%)\end{array}$ & $\begin{array}{c}\text { New } \\
\text { Marks } \mathrm{Z}_{\mathrm{i}}^{\text {+new }}\end{array}$ & $\begin{array}{c}\text { Old } \\
\text { Marks } \\
\mathrm{z}_{\mathrm{i}}^{+}\end{array}$ \\
\hline Financial process & 0.0267 & 0.0409 & 0.0141 & 52.9 & 4 & 3 \\
\hline Customers process & 0.0267 & 0.0345 & 0.0078 & 29.2 & 3 & 3 \\
\hline Review process & 0.0267 & 0.0663 & 0.0395 & 148.0 & 7 & 2 \\
\hline Progress process & 0.0762 & 0.1149 & 0.0387 & 50.8 & 11 & 8 \\
\hline $\begin{array}{l}\text { Performance } \\
\text { process }\end{array}$ & 0.0267 & 0.0411 & 0.0144 & 53.7 & 4 & 4 \\
\hline Quality process & 0.0566 & 0.0942 & 0.0377 & 66.6 & 9 & 5 \\
\hline Human-R process & 0.0566 & 0.0719 & 0.0154 & 27.2 & 7 & 5 \\
\hline Risk process & 0.1038 & 0.1399 & 0.0362 & 34.9 & 14 & 10 \\
\hline Financial result & 0.1557 & 0.0545 & -0.1012 & -65.0 & 5 & 17 \\
\hline Customers result & 0.0650 & 0.0163 & -0.0487 & -75.0 & 2 & 7 \\
\hline Review result & 0.0650 & 0.0434 & -0.0215 & -33.2 & 4 & 8 \\
\hline Progress result & 0.1300 & 0.0956 & -0.0345 & -26.5 & 10 & 12 \\
\hline Performance result & 0.0614 & 0.0564 & -0.0051 & -8.3 & 6 & 6 \\
\hline Quality result & 0.0614 & 0.0572 & -0.0042 & -6.8 & 6 & 5 \\
\hline Human- $R$ result & 0.0614 & 0.0729 & 0.0114 & 18.6 & 7 & 5 \\
\hline Process total & 0.3999 & 0.6037 & 0.2037 & 50.9 & 60 & 40 \\
\hline Result total & 0.6000 & 0.3963 & -0.2037 & -34.0 & 40 & 60 \\
\hline
\end{tabular}

Assume $\mathrm{h}^{\text {new }}\left(\mathbf{z}^{+ \text {new }}\right)$ as the evaluation function of allocated marks between the process categories and result categories considering the interdependence among categories. The difference between the new mark (new allocated mark) and the actual value of the evaluation function (performance value) is obtained by the following expression.

$$
\Delta \mathrm{h}^{\text {new }}(\mathbf{z})=\mathrm{h}^{\text {new }}\left(\mathbf{z}^{+ \text {new }}\right)-\mathrm{h}(\mathbf{z})
$$

Assume $\alpha$ as the threshold value, and the following is inferred.

When the difference (deviation value) between the performance value and new mark is greater than $\alpha$, take strong actions. In other words, if the deviation value is significantly different from the desirable value, taking greater actions for improvement contributes to the improvement of the PAI evaluation in the relevant category.

When the deviation value is within the range of $\alpha$, take ordinary actions instead of special actions. That is, the actions taken in this case are for general improvement, and they do not contribute to the improvement of the PAI evaluation in the relevant category.

When the deviation value is less than $-\alpha$, excessive evaluation is assumed and PMO does not take any actions. In such a case, the PAI evaluation in the relevant category will deteriorate.

The above are summarized as follows:

(1) If $\Delta \mathrm{h}_{\mathrm{i}}^{\text {new }}>\alpha,(\mathrm{Sgn})_{\mathrm{i}}=+1$

(2) If $\left|\Delta \mathrm{h}_{\mathrm{i}}^{\text {new }}\right|<\alpha,(\text { Sgn })_{\mathrm{i}}=0$

(3) If $\Delta \mathrm{h}_{\mathrm{i}}^{\text {new }}<-\alpha,(\operatorname{Sgn})_{\mathrm{i}}=-1$

In the above expressions (11), the Sgn function indicates that PMO judges the state of a project and whether or not they determine to take some actions by categories for stakeholders. 


\section{Prediction Precision of Action Model and Trial}

According to the PMO action model proposed by the authors, the relative error $\varepsilon$ between the prediction value of the next month and the performance value of the month is defined by the following expression (12),

Relative error $\varepsilon=\{($ Prediction value - Performance value $) /$ Performance value $\} \times 100$

Using the average value $\mu$ of the above relative error $\varepsilon$ and the standard deviation $\sigma$, the prediction precision criteria of the PMO action model are defined as follows:

(1) The more the average value approximates to zero, the higher the precision is evaluated.

(2) The less the standard deviation is, the higher the precision is evaluated since there is little deviation between prediction vale and performance value of each month.

Figure 7 shows the PAI evaluation performance values of 14 projects for the period from April 2006 through March 2007 (Yamato, 2005) (Yamato, Nakamura, 2006).

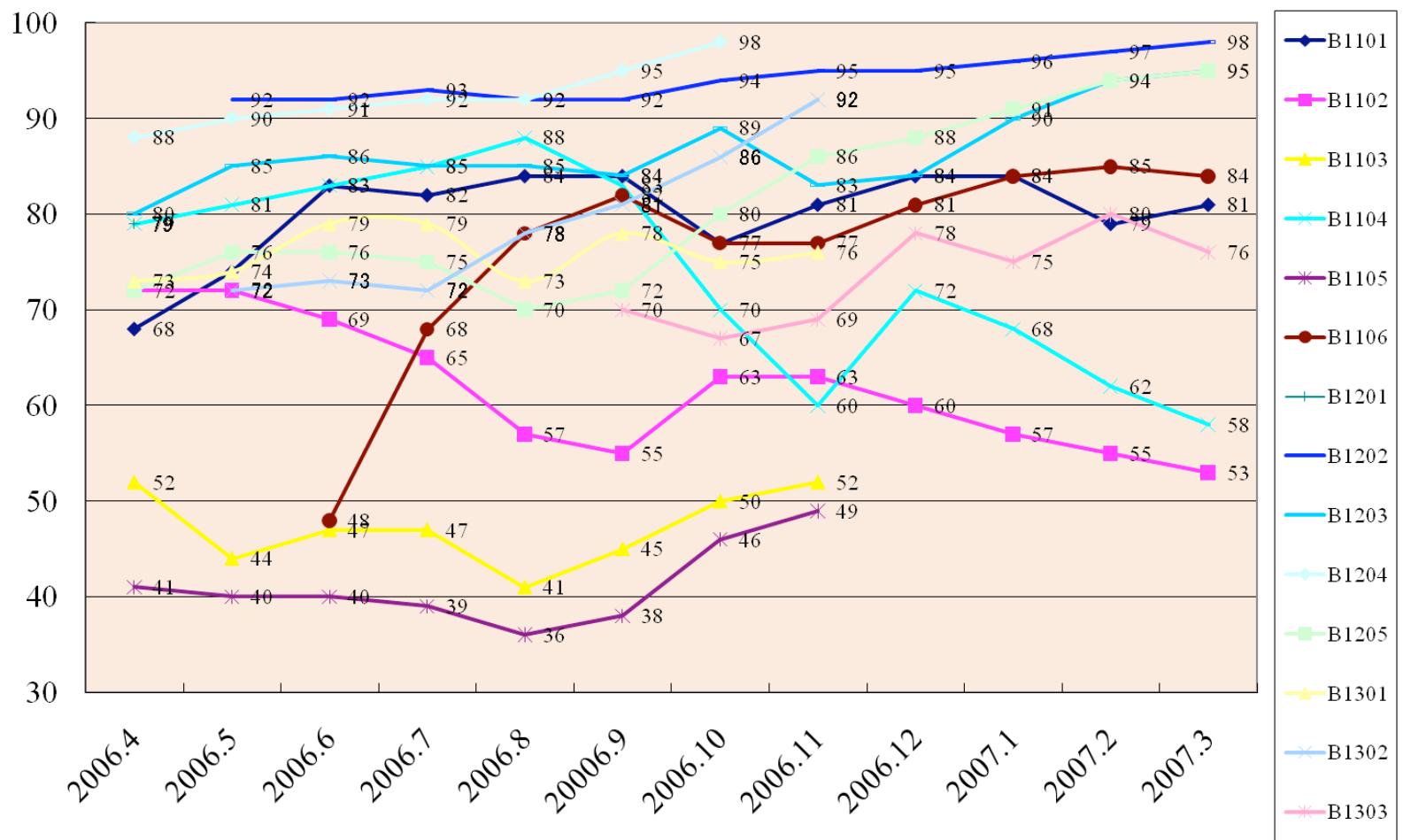

Figure 7. PAI Evaluation Performance Value Graph (April 2006 - March 2007) 
To evaluate the precision of PMO action model, three types of action level functions are transformed into seven cases, and the threshold value $\alpha$ is interchanged three times for each function. Table 5 lists the result of calculating the relative errors between prediction values of the PMO action model and PAI performance values (Kiefer,1977).

Table 5. Relative Errors between Prediction Values by Proposed Model and PAI Performance Values

\begin{tabular}{|c|c|c|c|c|c|c|c|c|}
\hline \multirow{2}{*}{\multicolumn{2}{|c|}{$\begin{array}{l}\text { Type of Action } \\
\text { Level Function }\end{array}$}} & \multirow{2}{*}{$\begin{array}{c}\text { Threshol } \\
d \text { value } \\
\text { of } \\
\text { Action } \\
\Pi \\
\end{array}$} & \multirow{2}{*}{$\begin{array}{c}\text { Average } \\
\mu\end{array}$} & \multirow{2}{*}{$\begin{array}{l}\text { Standaro } \\
\text { deviatio } \\
\text { n Я }\end{array}$} & \multicolumn{2}{|c|}{$\begin{array}{l}\text { 68\% Confidence } \\
\text { Interval }\end{array}$} & \multicolumn{2}{|c|}{$\begin{array}{l}\text { 95\% Confidence } \\
\text { Interval }\end{array}$} \\
\hline & & & & & $\begin{array}{l}\text { Lower } \\
\text { limit }\end{array}$ & $\begin{array}{l}\text { Upper } \\
\text { limit }\end{array}$ & $\begin{array}{l}\text { Lower } \\
\text { limit }\end{array}$ & $\begin{array}{l}\text { Upper } \\
\text { limit }\end{array}$ \\
\hline \multirow{3}{*}{\multicolumn{2}{|c|}{$\begin{array}{c}\text { Level Increasing } \\
\text { Type }\end{array}$}} & $\Pi=3$ & -0.79 & 6.53 & -7.33 & 5.74 & -13.86 & 12.28 \\
\hline & & $\Pi=2$ & -0.72 & 6.57 & -7.29 & 5.85 & -13.86 & 12.42 \\
\hline & & $\Pi=1$ & -0.81 & 6.59 & -7.40 & 5.78 & -13.99 & 12.37 \\
\hline \multirow{15}{*}{$\begin{array}{l}\text { Level } \\
\text { Constant } \\
\text { Type }\end{array}$} & \multirow{3}{*}{$\begin{aligned} & \Omega i \\
= & 0.00\end{aligned}$} & $\Pi=3$ & -0.81 & 6.44 & -7.24 & 5.63 & -13.68 & 12.07 \\
\hline & & $\Pi=2$ & -0.81 & 6.44 & -7.24 & 5.63 & -13.68 & 2.07 \\
\hline & & $\Pi=1$ & -0.81 & 6.44 & -7.24 & 5.63 & -13.68 & 2.07 \\
\hline & \multirow{3}{*}{$\begin{aligned} & \Omega i \\
= & 0.15\end{aligned}$} & $\Pi=3$ & -0.72 & 6.47 & -7.19 & 5.79 & -13.66 & 12.22 \\
\hline & & $\Pi=2$ & -0.65 & 6.48 & -7.13 & 5.83 & -13.61 & 12.30 \\
\hline & & $\Pi=1$ & -0.63 & 6.48 & -7.11 & 5.84 & -13.58 & 12.32 \\
\hline & \multirow{3}{*}{$\begin{array}{c}\Omega i \\
=0.23\end{array}$} & $\Pi=3$ & -0.67 & 6.53 & -7.19 & 5.86 & -13.72 & 12.39 \\
\hline & & $\Pi=2$ & -0.56 & 6.55 & -7.12 & 5.99 & -13.67 & 12.54 \\
\hline & & $\Pi=1$ & -0.53 & 6.57 & -7.11 & 6.04 & -13.68 & 12.62 \\
\hline & \multirow{3}{*}{$\begin{aligned} & \Omega \mathrm{i} \\
= & 0.38\end{aligned}$} & $\Pi=3$ & -0.58 & 6.69 & -7.27 & 6.11 & -13.96 & 12.80 \\
\hline & & $\Pi=2$ & -0.41 & 6.77 & -7.18 & 6.36 & -13.94 & 13.12 \\
\hline & & $\Pi=1$ & -0.36 & 6.87 & -7.22 & 6.51 & -14.09 & 13.37 \\
\hline & \multirow{3}{*}{$\begin{aligned} & \Omega \mathrm{i} \\
= & 0.62\end{aligned}$} & $\Pi=3$ & -0.44 & 7.11 & -7.54 & 6.67 & -14.65 & 13.77 \\
\hline & & $\Pi=2$ & -0.16 & 7.31 & -7.47 & 7.15 & -14.78 & 14.46 \\
\hline & & $\Pi=1$ & -0.08 & 7.61 & -7.69 & 7.54 & -15.31 & 15.15 \\
\hline \multirow{3}{*}{\multicolumn{2}{|c|}{$\begin{array}{l}\text { Level Decreasing } \\
\text { Type }\end{array}$}} & $\Pi=3$ & -0.47 & 6.79 & -7.26 & 6.31 & -14.04 & 13.10 \\
\hline & & $\Pi=2$ & -0.25 & 6.86 & -7.12 & 6.61 & -13.98 & 13.47 \\
\hline & & $\Pi=1$ & -0.04 & 7.03 & -7.07 & 6.99 & -14.1 & 14.03 \\
\hline
\end{tabular}


For example, a graph of relative errors (level increasing type $\Omega_{\mathrm{i}}$ and threshold value $\alpha=1.0$ ) is given in the following Figure 8.

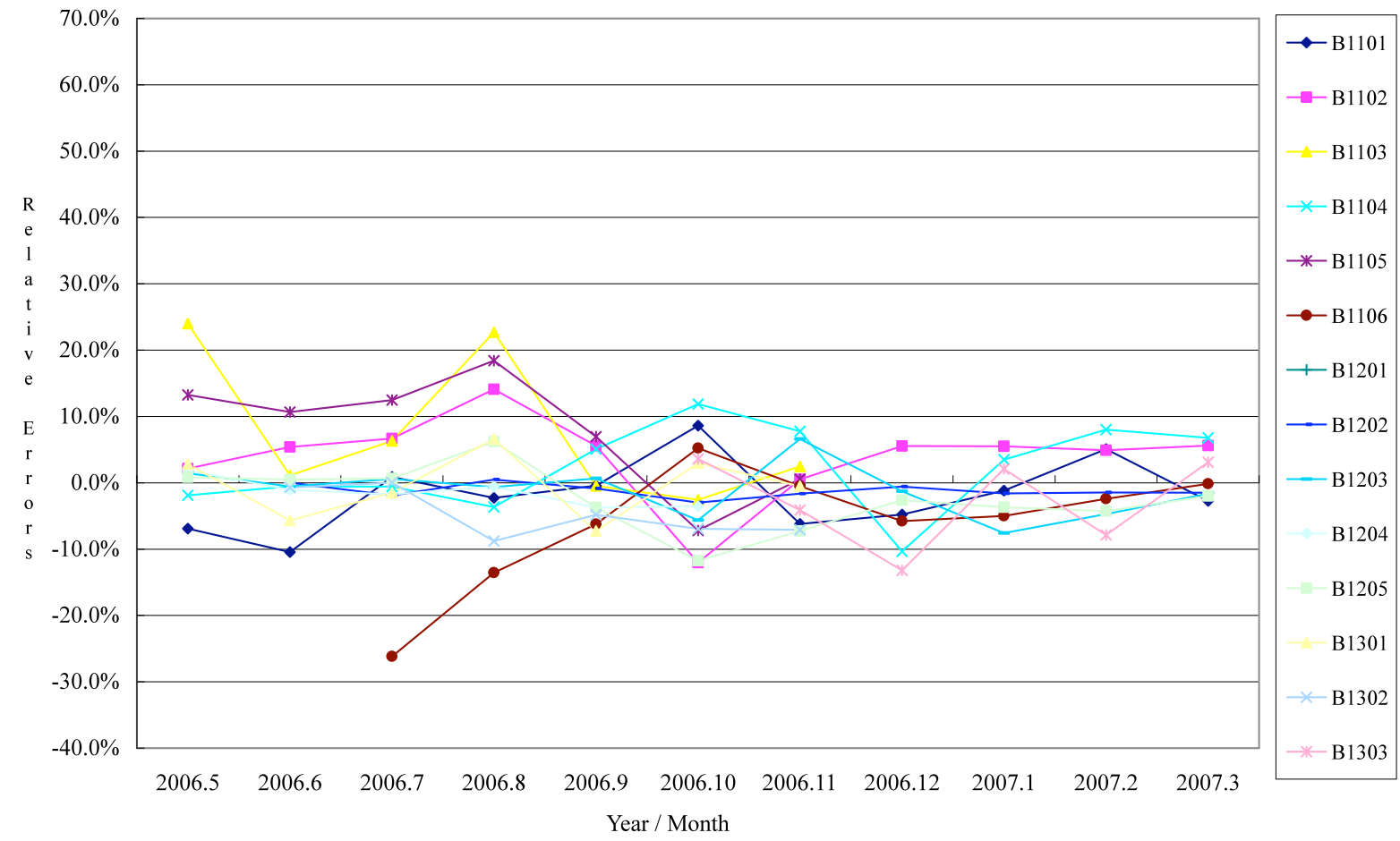

Figure 8. Relative Errors between Prediction Values by Proposed Model and PAI Performance Values (level increasing type $\Omega_{\mathrm{i}}$ and threshold value $\alpha=1.0$ )

According to the statistical theory, it is known that, when the number of sampling data exceeds 30 , no great difference is observed if sample variance is assumed to be the variance of parent population. The data used for plotting the above graph are those of 14 projects for 113 sampling times for the period of 12 months in each case. Therefore, it can be said that the standard deviation of sampling data may be used as is for the standard deviation of the parent population (Sheldon, 2004).

The evaluation is made according to the prediction precision criteria of the proposed PMO action model.

(1) Threshold value and precision of model

When the threshold value is 1 , the average value $\mu$ of the relative error, which is the evaluation index of this proposed model, tends to become lower. If only a little deviation between a new allocated mark and performance value, the prediction value of a model to which actions are taken reflects well the performance value. This agrees with the attitude to take actions and to improve a project if only a little deviation is found between the desirable value and performance value. Meanwhile, the lower the threshold value becomes, the greater the standard deviation $\sigma$ of the relative error becomes, which means that the variance of the relative errors between prediction values and performance values becomes greater.

(2) Action level functions and precision of model

In the cases of the level-decreasing type action level $\Omega_{\mathrm{i}}$ and level-constant type $\left(\Omega_{\mathrm{i}}=0.629\right)$, the similar tendency is found, where the average value $\mu$ of the relative errors become lower. In the cases of the level-increasing type action level $\Omega_{\mathrm{i}}$ and level-constant type $\left(\Omega_{\mathrm{i}}=0.0000\right)$, the similar tendency is also found, where the standard deviation $\sigma$ of the relative errors become lower. As shown in Figure 7, the projects subject to investigation are divided into two groups: those having the PAI performance value of 
85 or more, and those having the PAI performance value of 50 or lower. The level-decreasing type seems to suit for the model of relatively high group, and the level-increasing type seems to suit for the model of relatively low group. The level-constant type may be regarded as an intermediate model between the above models.

\section{Conclusion}

This paper has revealed the possibility to construct a prediction model for the state of a project, where the average of the relative error between the prediction value of the next month and the performance value of the month is $1 \%$ or fewer and the standard deviation is six to seven percent.

To apply this model in practical use, it must be taken in to consideration that various factors affect the state of a project; however, the authors believe that this proposed model is sufficiently applicable.

By incorporating a mechanism enabling to choose a model type according to the maturity of a target project, it is expected that the applicability and precision will be dramatically higher in the future.

\section{Acknowledgment}

This work was partially supported by Grant-in-Aid for Scientific Research (A) (20241042) from MEXT and JSPS.

\section{REFERENCES}

Abramowitz, Milton., Stegun, Irene. A. (1970). Handbook of Mathematical Functions with Formulas, Graphs, and Mathematical Tables. New York : Dover Publications, Ninth printing.

Kiefer, J. (1977). Conditional Confidence Statements and Confidence Estimators (with discussion). Journal of the American Statistical Association, 72, 789-827.

Saaty, T. L. (1980). The Analytic Hierarchy Process. New York, N.Y.: McGraw Hill.

Sheldon, M. Ross. (2004). Introduction to Probability and Statistics for Engineers and Scientists Third Edition. Burlington, MA, Elsevier Academic Press.

Yamato, S. (2005). The Role of the Communications Management in PMO Activity. Journal of the Society of PROJECT Management (in Japanese) ,7(1),9-14.

Yamato, S., \& Nakamura, J. (2006). Project Quantitative Assessment Indicators and PMO Actions for Project Maturity Model. 3rd International Conference on Project Management National Conference. CS10D.

Yamato, S., Nakamura, J., \& Honma, T. (2008). Quantitative Project Assessment using the AHP Absolute Measurement Method, PROCEEDINGS 15th National Conference of The Society of PROJECT Management ,314-319.

Yamato, S., Nakamura, J., \& Honma, T. (2008). PMO Action Model using AHP. 4th International Conference on Project Management National Conference, W3B3. 